\title{
5 Mining in the Philippines: a Catholic peacebuilding approach
}

\author{
Karl M. Gaspar, CSsR
}

In the Philippines, as in other countries examined in this book, mining is intricately connected to issues of peace, human rights, development, and ecology. Since Vatican II and especially since its role in the People Power movement that brought down the Marcos regime, the Catholic Church in the Philippines has been an influential force for social justice and peace. This essay connects the church's history of engagement on these broader issues over the past five decades to its more recent engagement on mining.

\section{Conflicts in the Philippines}

Since the Philippines gained independence in 1946, its situation has always been volatile, especially on the southernmost island of Mindanao. In the 1950s and 1960s, government forces crushed armed bands of Islamic Moros (see Constantino and Constantino 1978; Diokno 1987). A more determined armed resistance arose with the founding of the Moro National Liberation Front (MNLF), a separatist movement which began to recruit rebels in 1969 (Gaspar, Lapad, and Maravillas 2003, 29-30; see also Vitug and Gloria 2000). Violent encounters between MNLF and government forces took place across parts of Mindanao from 1972-75. In 1976, Libyan leader Muammar Gaddafi brokered a short-lived cessation of hostilities between the government and the MNLF. The signing of this agreement brought about a serious rift in MNLF leadership, leading to the formation of a breakaway group that established the Moro Islamic Liberation Front (MILF) in 1984.

In January 1987, the MNLF accepted the Philippine government's offer of semi-autonomy for the regions in dispute, leading to the establishment of the Autonomous Region of Muslim Mindanao on November 6, 1990. The MILF, however, refused to participate. As government administration changed from one president to another, peace talks were initiated but never succeeded. It was during the presidency of Rodrigo Duterte that the government and the MILF finally agreed on the Bangsamoro Organic Law, signed by President Duterte on July 26, 2018, and approved by plebiscite in early 2019. Consequently, the Bangsamoro Transitory

DOI: $10.4324 / 9781003094272-5$ 
Parliament was established and is currently laying down the groundwork for a governance system.

However, it was not only the Moro rebellions that the state has had to deal with since the early 1970s. Whereas these only involved territories in the Muslim areas in Mindanao, the revolution that has been waged by the Communist Party of the Philippines (CPP) - with its military arm, the New People's Army (NPA)-operated across the country (see Sison 2013; Reid 2000). Fighting a guerrilla war against the state, the CPPNPA remains an underground operation aimed at overthrowing the Philippine government, implementing a radical land-reform program, promoting a national economic policy, and ending US imperialist influence over its former colony. It has survived six presidents and remains a force to reckon with. In the wake of the People Power uprising in 1986, which installed Cory Aquino as successor to Ferdinand Marcos, the first peace talks between the state and the CPP-NPA were convened. They collapsed owing to the state military's belligerence. The talks were resurrected by other administrations, but would always begin with high hopes and end with bitter frustration on both sides (see Bolasco 2019). Duterte has expressed his interest in resuming talks, but only time will tell if he can succeed in finally ending this insurgency that has lasted more than fifty years.

As these rebellions have raged across the country, the civilian population has suffered considerable collateral damage. Farmers, fisherfolk, and indigenous peoples have been the most victimized by the consequences of military operations, which have often led to human rights violations (ABS-CBN Investigative and Research Group 2018).

\section{Violent conflict, human rights violations, and mining}

Holden and Jacobson (2007) lay out how mining worsens and prolongs violent conflict in the Philippines. First, mining companies and armed groups are frequently at odds simply because mining is most common in regions that have the preferred terrain for guerrilla warfare; this is especially true in Mindanao $(485,487)$. But that tension is only a starting point. Territorial rivalry makes mining companies clear targets for extortion. Holden and Jacobson cite one example of a company that was found to have paid over US $\$ 1.7$ million to several different armed groups (487). This funding increases the capacity for guerrilla groups to wage war, while at the same time, robust fear and distrust of mining companies throughout the Philippines, especially in rural areas that depend heavily on environmental resources damaged by mining operations, gives armed groups fertile ground for recruitment (489). Further, mining companies are tangible symbols of the globalized economic system despised by the ideology of armed militants, making them appealing targets for attacks and furthering their usefulness as foils to enhance recruitment (489). 
Given these risks, the typical response at mining sites has been increased militarization. National armed forces and private security have been quick to cast all opposition to mining as terrorism, or as in league with armed insurgents, leading armed security and military forces around mining operations to be draconian (490-92).

With this sort of pattern, human rights abuses have been common. Since the passage of the 1995 Mining Act, the media, indigenous persons organizations, and other civil society organizations (CSOs), many of which are faith-based, have reported violence and human rights violations, especially when mining projects face aggressive resistance. These have included reports on "beatings, maiming, intimidation, torture, extra-judicial killings or summary executions, abductions, and enforced disappearances in what is widely viewed as state-sponsored or state-protected terrorism" (Goodland and Wicks 2008, 44). Human Rights Watch identified anti-mining activists as victimized along with other groups active in the resistance movement, including political and student activists, journalists, and church workers (Shepherd and Neumann 2007, 2, 28).

Indigenous communities in particular have had a sordid history with human rights violations related to mining. In 2001, a report detailed how mining operations were violating the rights of the Subanens in the Zamboanga area of Mindanao (Sanz 2001). The report was issued by researchers who conducted a human rights impact assessment of the TVI Resource Development's Canatuan mine. It looked into six core human rights: self-determination, security, adequate standard of living, adequate housing, work, and education. It indicated that the mine had a negative impact on the right to self-determination and on local selfgovernance. The operation was also found to have forced evictions and increased militarization of the area around the mine, and to have "had a negative impact on the ability of the Subanon [sic.] to enjoy the human right to security and the human right to housing. Mining activity appears to have increased the levels of sediment and metals in some local waterways, threatening the human right to an adequate standard of living" (53).

A final point that Holden and Jacobson (2007) make about mining and conflict in the Philippines is that mining economically marginalizes large scores of the Philippine population. Mining has a poor record of job creation and high risk for environmental costs that inhibit people from engaging in other livelihoods, factors that leave poor people even poorer and disenfranchised people even more disenfranchised (494-96). This creates greater social instability that exacerbates existing conflict factors. Combine this economic problem with rampant corruption in the mining sector (492-93) and the militarization described above that increases tensions, introduces human rights violations, and enriches militants while strengthening their recruitment platforms, and mining and conflict become locked in an escalating spiral. 


\section{The Church's response to conflict, human rights, and environmental concerns}

The engagement of the Church in the Philippines on mining is best understood in the context of its wider efforts to address issues of peace, justice, and ecology from the Marcos era to the present. Mainly through the Catholic Bishops' Conference of the Philippines (CBCP) and the MindanaoSulu Pastoral Conference (MSPC), the church took a strong prophetic stance to denounce human rights violations during the Marcos regime.

Between 1977 and 1979, a new challenge confronted the bishops. On one hand, seven years of Marcos's dictatorial rule further worsened as poverty increased, foreign debt accumulated, Imelda Marcos's lifestyle became more scandalous, corruption in the bureaucracy now involved most of Marcos's cronies who monopolized control over government corporations, and human rights violations skyrocketed as more suspected "subversives" were arrested or assassinated. At the same time, the underground communist movement had become quite popular. Reacting to this situation, the CBCP issued the 1979 pastoral letter "An Exhortation Against Violence." They critiqued violent reactions to the nation's problems, and described this situation as follows:

The daily newspapers are filled with accounts of military encounters, of ambushes and killings, not to mention the more ordinary crimes, the scandals of corruption and other forms of violence. Revolutionary groups are increasing in number and escalating the spirit (and in some cases the praxis) of violence, especially among the urban and rural workers, intellectuals and students, and among a number of dedicated and concerned Christians, including some clerics and religious. (n.p.)

In clear terms they stated that, "In the world where violence all too frequently maims and destroys the personal and sacred lives of men, we must uphold the violence of love and the peace of Christ over hate and destructive violence ... The option of non-violence must be respected as one Christian option, as a Christian pattern of action" (n.p.). The statement ends with an exhortation towards justice and peace. It was no surprise that such phrases would appear in the bishops' statement, as they were worried that some priests, religious, and seminarians were becoming more sympathetic to the communist movement.

In February 1983, the CBCP (1983a) issued a new pastoral letter reacting to the military's arrest of priests and religious and lay church workers, many of whom became political prisoners. They denounced such human rights violations and cited the reasons why they were supporting the struggles of the poor, deprived, and oppressed, pointing back to the 1971 Synod on Justice. Six months later, on August 21, on his return to the Philippines from exile in the United States, Senator Benigno "Ninoy" 
Aquino was assassinated on the Manila airport tarmac. With his martyrdom, the protest movement grew by leaps and bounds. However, such a movement only provoked more repression, prompting the bishops to issue a statement on reconciliation. They acknowledged that "many events have pushed our country closer to the brink of chaos and anarchy," and reiterated "the need for reconciliation as an alternative to the continuance of present injustice and violence which would put one against another in a bloodbath of revolution where the Gospel ethic of love would undeniably be sacrificed." Once more, they highlighted the path of "the non-violence of Christ ... as the only acceptable answer," as it is "a way of working constantly, strenuously for justice that refuses adamantly to destroy life for the cause of justice itself" (СBCP 1983b).

Another church body that was a major force for peacebuilding was the MSPC, constituted in 1971 by the dioceses of Mindanao-Sulu and meeting every three years. In the first two conferences, the delegates became more vocal in their opposition to martial law, which was declared in 1972 (see Gaspar 1977). At the MSPC in 1984, they demanded that Marcos lift martial law and return to the country's democratic tradition. However, martial rule only worsened. Instead of bringing about peace and order, there was more dislocation of communities given the twin evils of incursions into the countryside by corporations and the ensuing militarization that usually led to abuses committed by the armed and paramilitary forces providing security.

While the bishops' conference had not spoken about the Moro rebellions and the impact of violence on the citizenry, the MSPC conferences since the beginning expressed their concern for the plight of the Moro and the escalation of armed encounters leading to mass evacuations and human rights violations. They also discussed the impact of martial rule on the lives of indigenous peoples, whose situation could only be reported because of the presence of missionaries in their isolated territories. The chair of the conference, Bishop Bienvenido Tudtud, proposed beginning an interfaith dialogue with the Muslims which led to a program known as Duyog Ramadhan, a community-based activity where Muslims and Christians came together for a dialogue of life and faith. It also led to the establishment of the Bishops-Ulama Conference, a forum bringing together Christian and Muslim leaders which became instrumental in peacebuilding efforts. Meanwhile, the missionary congregations engaged in advocacy work among indigenous communities and began to come up with collaborative efforts to help protect them from the abuses of the martial law regime as well as to empower them to stand firm on their rights.

In the midst of these peacebuilding efforts, the mining and logging industries attracted attention from some church groups, as these were promoted as money-making ventures for Marcos and his cronies. Logging firms 
were owned primarily by Filipino oligarchs, a number of whom had run for political office so they could take advantage of their position in government to protect their interests. The few Filipino mining companies-again, owned by oligarchs who also owned other businesses, especially in manufacturing and trading - partnered with Western firms to mine gold, silver, and copper in various parts of the country. During the Marcos regime, however, no one had yet heard of global warming and climate change and how deforestation and mining contribute to this ecological crisis. And as many other justice and peace issues were more urgent, there were not many actions to protest the expansion of mining and logging.

\section{The shift to ecological advocacy}

From the time of the American occupation to the contemporary period, there has been no let-up in deforestation (see Forest Management Bureau 2009). But for a long while massive deforestation and the expansion of agribusiness plantations were not a major concern of the Church in Mindanao. The first stirrings that would lead to a nascent church movement engaged in ecological issues arose in the late 1980s in two areas: San Fernando, Bukidnon, and Midsalip, Zamboanga del Sur. This pastoral engagement was provoked by peasants' concerns about land-grabbing and the impact of logging in limiting water that could be tapped for their irrigated rice fields. The fact that the peasant communities were organized in vibrant base ecclesial communities and had the support of their missionaries made possible anti-logging mass actions that succeeded in terminating logging operations in the area.

These grassroots-based ecological actions influenced the CBCP (1988) to issue the pastoral letter "What is Happening to Our Beautiful Land?" As the mining problem had not yet become urgent, the statement hardly referred to this issue. However, it exhorted the government "not to pursue short term economic gains at the expense of long-term ecological damage" (n.p.). In a context when 29 out of the 30 million hectares of the country's primary forests had been destroyed, the bishops claimed that awareness of the relationship of people to the environment had continued to grow and that destroying the forests was sinful. They posited that "As people of the covenant we are called to protect endangered ecosystems like the forests, mangroves and coral reefs and to establish just human communities in our land" (n.p.).

Henceforth, the concern for ecological advocacy within the church began to slowly expand from diocese to diocese. In many cases, civil society organizations assisted them. One that was very active in the Davao area was the Kinaiyahan Foundation, and later the Interfacing Development Initiatives for Sustainability (IDIS). Various church groups supported IDIS's unfortunately unsuccessful campaign to end aerial spraying in banana plantations. 


\section{Church action and advocacy around mining}

Mining became a focus of the Catholic community's ecological concern in the mid-1990s. Mining, especially open pit mining, became contentious following the Congress's approval of the Philippine Mining Act in 1995, which "liberalized the legal framework for mining, making it far less restrictive," as it allowed "greater foreign ownership, full repatriation of profits, tax breaks and tax holidays for five to ten years, and lower duties and tariffs" (Goodland and Wicks 2008, 23). Consequently, there arose a strong interest on the part of mining firms to expand their present operations and/or explore new territories where significant deposits of mineral resources had been identified. As soon as the Mining Act was passed in 1995, there was a huge rush of applications. Under the new law, two different licenses existed: Mineral Production Sharing Agreements (MPSAs), which limited foreign ownership of a project to $40 \%$, and Financial and Technical Assistance Agreements (FTAAs), which allowed full foreign ownership. Before the major push toward expanding the area of mining coverage, there were just a few existing MPSAs, with only two existing FTAAs that covered 447,308.26 hectares. After the passage of the Mining Act, 54 more FTAA applications targeting 2,350,643.34 hectares were approved (Goodland and Wicks 2008, 25).

But the Act did not go uncontested. A few quarters within the government bureaucracy and civil society, including the La Bugal-Blaan Tribal Association of Mindanao, claimed the Act violated the 1987 Constitution's provision that "all lands of the public domain, waters, minerals, coal, petroleum and other mineral oils, all sources of potential energy, fisheries, forests, timber, wildlife, flora and fauna and other natural resources are owned by the state." Citing the devastating effects of some of the mining operations, such as spillages of mine tailings, the CBCP $(1998$, n.p.) argued that "the adverse social impact on the affected communities, especially on our indigenous brothers and sisters, far outweighs the gains promised by large-scale mining corporations." They then proposed that the government repeal the Act and recall all approved FTAAs and mineral agreements and disapprove the pending ones. Owing to the pressure from CSOs and the church, in 2004, the Supreme Court ruled the Mining Act was unconstitutional.

The state did not give up so easily and used all its power to pressure the Supreme Court to reverse their ruling. Ten months later, the Supreme Court changed its mind. President Macapagal-Arroyo immediately issued an executive order known as the National Policy Agenda on Revitalizing Mining. This provoked more protests as this decision impacted various stakeholders, including municipal and provincial government authorities, the church, and other CSOs, who all continued to pressure the Supreme Court to revert to its original decision. 
Once more in 2006, the CBCP expressed its support for the many petitions against mining operations and re-affirmed its stand for the repeal of the Mining Act of 1995. The bishops stated that allowing the interests of big mining corporations to prevail over people's right to preserve natural resources necessary for their livelihoods was tantamount to violating their right to life as well as threatening their health and environmental safety. All kinds of mining destroyed the environment while depriving the people of the land they should be cultivating for their subsistence. Especially in relation to indigenous peoples, the bishops made it clear they were against any mining firm that would dislocate them from their ancestral domain.

In 2008, Leila de Lima was appointed chairperson of the country's Commission on Human Rights. She was aggressive about pursuing cases of human rights violations, and CSOs and church personnel could seek her assistance in following-up reports of violence. One such case took place in the village of Kasibu in the province of Nueva Viscaya on November 5-6, 2009. This location was where the mining operations of Oceana Gold Philippines, Inc. took place. The local parish supported de Lima's investigative campaign. It was a breakthrough case as an agency in government was seen as taking a strong position against human rights violations and giving peacebuilders and rights defenders an ally.

In the next few years, the CBCP continued its advocacy against mining. A July 2010 letter from Nerio Odchimar, Bishop of Tandag, to President Benigno Aquino III reiterated the bishops' decade-old request that the government put a stop to large-scale mining "since this not only permanently damages the delicate balance of the natural environment, but it also makes our small farmers, fisher folks and IPs [indigenous persons] suffer." In 2010, the Department of Environment and Natural Resources (DENR) issued Administrative Order No. 2010-21. This order formally amended the provisions of the 1995 Mining Act, upholding the principle that public domain lands, including those with natural resources like minerals, are owned by the state, and making space for the rights of indigenous persons in accordance with the 1997 Indigenous Peoples Rights Act.

The 2010 DENR order did not immediately resolve all disputes and tensions, as despite its safeguards, the liberalization of the industry continued to usher a massive expansion of mining exploration and operation; thus, the church's advocacy against mining persisted. The Association of Major Religious Superiors in the Philippines (2013) issued a joint statement on mining and greater solidarity with the poor. Appealing to their roles as stewards of the environment and as shepherds to indigenous communities, the religious superiors continued to lobby for policies protecting our common home against environmentally destructive activities. The visit of Pope Francis to Manila in January 2015 provided an opportunity for the CBCP's Secretariat for Social Action to issue a joint letter co-signed by Alyansa Tigil Mina (2015), an advocacy network for 


\section{Karl M. Gaspar, CSsR}

mining justice. The letter referred to a message of Pope Francis during a Day of Reflection between the Vatican and mining executives that reminded everyone that "the great challenge of business leaders is to create a harmony of interests, involving investors, managers, workers, their families, the future of their children, the preservation of the environment on both a regional and international scale, and a contribution to world peace" (n.p.).

Claiming the need to add to the gross national product while providing employment and increasing government revenues, administrations since President Macapagal-Arroyo have encouraged more investment in mining. At the start of his term in 2016, President Duterte appointed a secretary to the DENR who was staunchly anti-mining. But pressure from both the mining oligarchs and their supporters in Congress prevented confirmation of her appointment, and that ended this initial attempt to limit mining. Since then, Duterte has fully backed the expansion of mining, providing the same rationale as previous administrations. It is in Mindanao where most mining explorations are being pursued, including the new Bangsamoro areas and areas where indigenous communities like the Lumad and the Subanen reside.

In 2019, the bishops issued a statement supporting all those who continue to oppose mining. In the statement, they once more called the faithful's attention to the threat of extractive mining operations and reiterated that:

Social justice is not served when only the few mining companies, many of which are also owned by political leaders, reap the benefits from mineral extraction. The rural poor remain poor as mining only contributes less than one percent to our GDP, employs less than $0.4 \%$ of our labor force, and directly threatens agriculture, forestry, watersheds and fisheries resources that are essential for the survival of the rural poor. (CBCP 2019, n.p.)

One specific type of mining this statement addressed was coal. The state has aggressively promoted coal because of increased reliance on coal-fired power plants and a desire to reduce reliance on foreign coal to fuel them. Across the country, these plants have sprouted in various places. The CBCP statement observed that by the end of 2020 there were expected to be over fifty operational coal plants and 186 coal-mining projects. Many are located in areas that have rich ecosystems and are mostly inhabited by indigenous peoples. The statement affirmed scientific evidence of coal causing climate degradation, and stated that "Coal projects also further exacerbate the vulnerability of impoverished host communities in the Philippines already struggling to cope with the effects of the worsening climate" (n.p.). Consequently, according to the bishops, coastal and agriculture-reliant communities have experienced losing their livelihoods because of land 
conversion and have experienced adverse health impacts due to pollution as toxic substances and heavy metals are released into the air.

Local government officials and indigenous leaders in all these areas are being wooed by mining firms that desire to begin operations soon. Where they have resisted, the people have been subjected to harassment and human rights violations. One area where this has been taking place is between the Diocese of Marbel and the Archdiocese of Cotabato, where coal deposits were recently discovered. The local social action centers opposed the opening of such operations and supported the indigenous communities who took a stand to oppose the coal mining.

Another major development that spurred strong church response occurred in 2021. President Duterte's EO 130 amended President Aquino III's EO 79 from 2012 to lift a moratorium on mineral contracts in protected areas, prime agricultural lands, tourist areas, and other critical locations. Caritas Philippines and other church actors strongly opposed Duterte's decision, contending it would harm the environment while mainly benefiting business interests, not the poor. Nine provinces in Mindanao, including Moro and Lumad areas, would be impacted by lifting the moratorium (Gomes 2021). The church's ability to respond to Duterte's decision was enhanced by Eco-Convergence, a church-civil society partnership to promote Laudato Si'. Eco-Convergence Hubs throughout the Philippines that track data and develop local expertise in monitoring mining operations enabled church leaders to highlight the likely impact on their communities of the lifting of the moratorium.

This recent affair points to one very important thing local churches will need if they are to sustain their advocacy against mining: data on how the mining industry is playing out in their specific territories. Information is not difficult to obtain, as it is publicly available online and there are media institutions interested in filing reports on mining explorations. By knowing exactly what sort of mining is operating or is planned in their respective dioceses, the local churches would be able to provide the data to their constituencies that is needed to formulate effective advocacy.

For example, one of the most vibrant forms of church action with regard to mining has been grassroots efforts to create opportunities for alternative economic activities in areas marked for mining development. In an interview with Holden and Jacobson (2007, 496), I discussed the widespread, parish-level efforts of base ecclesial communities in Mindanao to foster bottom-up development with activities like organic farming, microfinance, and handicrafts. These sorts of localized development projects, supported by local churches and encouraged in seminary training, are small but powerful vehicles for resisting the dominant power of the globalized mining industry. And it is essential that leaders are able to access accurate and up-to-date data on what the government and mining companies are doing and planning to do in their areas, as well as what impacts can be expected. 


\section{Conclusion}

Since the country gained independence, social unrest has characterized Philippine society. Over the decades, a robust matrix of civil society work for peace has evolved. This has included labor organizing, youth movements, advocacy groups, and the influential People Power Revolution of the 1980s. These efforts came to also include conscientization programs so that the poor and disadvantaged would be made aware of the root causes of their marginalization. The formation of leaders assured that the empowerment of the poor would be sustained as the struggles would take time, and the mobilization of resources was also assured.

Another decades-long problem has been armed insurgencies. Unrest and violent conflict have been constants. As with other areas of social unrest, civil society organizations have also been deeply embedded in peacebuilding work in affected conflict zones and have made real progress. The various agencies operating under the Catholic Church, from episcopal commissions to diocesan pastoral centers to religious orders, have been influenced by and helped shape these efforts for justice and peace. The Church in the Philippines has been one of the most active and effective peacebuilding organizations in the country, and remains engaged on a range of issues, including ones related to ongoing strife with the government as well as with armed groups. Some of the factors that have made Catholic engagement effective in reducing violent conflicts and creating conditions for a just and sustainable peace include the following: strong social and symbolic capital; the wise use of a prophetic role that can influence a wide range of the population, including state officials as well as those holding corporate power; and vibrant base ecclesial communities.

Today, this peacebuilding capacity is being exercised in areas where there is conflict associated with mining explorations and operations. Mining has become a focal point of the government's economic development plans, and aggressive pushes to increase mining output, especially in the southern region of Mindanao, have introduced waves of human rights violations, violence, and new and worsened vulnerabilities for communities already dealing with the effects of decades of conflict. Indigenous peoples have been particularly impacted. These mining conflicts interweave environmental questions, human rights issues, social cohesion and conflict transformation challenges, poverty and economic marginalization, and indigenous rights. In this light, the church's experience with varied peacebuilding activities across levels of society, with developed sensitivity to ecological concerns, offers important resources to respond to these problems.

\section{References}

ABS-CBN Investigative and Research Group. 2018. "By the Numbers: Human Rights Violations During Marcos' Rule.” ABS-CBN News, September 21, 2018. 
https://news.abs-cbn.com/focus/09/21/18/by-the-numbers-human-rights-violations-during-marcos-rule.

Association of Major Religious Superiors in the Philippines. 2013. AMRSP Convention Statement. AMRSP Joint Biennial Convention, Davao City, July 1-5, 2013. http:// www.pddm.ph/index.php/news/news-and-updates/1647-amrsp-convention-statement.

Bolasco, Maria Karina Africa. 2019. “The GRP-NDFP Peace Talks: Tactical Discontinuities in a Shared Narrative." Kyoto Review of Southeast Asia, Trendsetters 26. https://kyotoreview.org/trendsetters/grp-ndfp-peace-talks.

CBCP (Catholic Bishops' Conference of the Philippines). 1979. "Exhortation Against Violence." https://cbcponline.net/exhortation-against-violence-a-jointpastoral-letter-of-the-philippine-hierarchy.

CBCP (Catholic Bishops' Conference of the Philippines). 1983a. "A Dialogue for Peace.” https://cbcponline.net/a-dialogue-for-peace-joint-pastoral-letter-catholicbishops-conference-of-the-philippines.

CBCP (Catholic Bishops' Conference of the Philippines). 1983b. "Reconciliation Today." https://cbcponline.net/reconciliation-today.

CBCP (Catholic Bishops' Conference of the Philippines). 1988. "What is Happening to our Beautiful Land?" https://cbcponline.net/what-is-happening-to-our-beautiful-land.

CBCP (Catholic Bishops' Conference of the Philippines). 1998. "A Statement of Concern on the Mining Act of 1995." https://cbcponline.net/a-statement-ofconcern-on-the-mining-act-of-1995.

CBCP (Catholic Bishops' Conference of the Philippines). 2006. "Mining Issues and Concerns." https://cbcponline.net/a-statement-on-mining-issues-and-concernsdo-not-defile-the-land-where-you-live-and-where-i-dwell-num-3534/.

CBCP (Catholic Bishops' Conference of the Philippines). 2019. "An Urgent Call for Ecological Conversion, Hope in the Face of Climate Emergency." https://cbcpnews.net/cbcpnews/an-urgent-call-for-ecological-conversion-hope-inthe-face-of-climate-emergency.

Catholic Bishops' Conference of the Philippines National Secretariat for Social Action/Caritas Philippines and Alyansa Tigil Mina. 2015. "Joint Statement on the Mining Issue During the Visit of Pope Francis in Manila and Tacloban in the Philippines: 15-19 January 2015." https://hronlineph.com/tag/catholic-bishopsconference-of-the-philippines.

Constantino, Renato, and Letizia R. Constantino. 1978. The Philippines: The Continuing Past. Quezon City: The Foundation for Nationalist Studies.

Diokno, Jose W. 1987. A Nation for Our Children: Human Rights, Nationalism, Sovereignty: Selected Writings of Jose W. Diokno. Quezon City: Claretian Publications.

Forest Management Bureau. 2009. "Philippines Forestry Outlook Study." Working Paper No. APFSOS II/WP/2009/10, Asia-Pacific Forestry Sector Outlook Study II. Food and Agriculture Organization of the United Nations Regional Office for Asia and the Pacific. http://www.fao.org/3/am255e/am $255 \mathrm{e} 00 . \mathrm{pdf}$.

Gaspar, Karl. 1977. "The Growth and Development of MSPC.” In What is MSPC?, 14-17. Davao City: MSPC Publications.

Gaspar, Karl, Elpidio A. Lapad, and Ailynne J. Maravillas. 2003. Mapagpakamalinawon: A Reader for the Mindanawon Peace Advocate. Davao City: Alternate Forum for Research in Mindanao. 


\section{Karl M. Gaspar, CSsR}

Gomes, Robin. 2021. "Philippine Church Decries Government Lifting Ban on Mining." Vatican News, April 21, 2021. https://www.vaticannews.va/en/church/ news/2021-04/philippines-caritas-bishops-against-lifting-ban-mining.html.

Goodland, Robert, and Clive Wicks. 2008. Philippines: Mining or Food?: Chapters 1 to 7. London: The Working Group on Mining in the Philippines. http:// www.piplinks.org/miningorfood.html.

Holden, William N., and R. Daniel Jacobson. 2007. "Mining Amid Armed Conflict: Nonferrous Metals Mining in the Philippines." The Canadian Geographer 51, no. 4: 475-500. 10.1111/j.1541-0064.2007.00193.x.

Odchimar, Nerio. 2010. Nerio Odchimar, Bishop of Tandag, to Benigno Simeon C. Aquino, III, President of the Republic of Philippines. July 12, 2010.

Reid, Ben. 2000. Philippine Left: Political Crisis and Social Change. Manila: Journal of Contemporary Asia Publishers.

Sanz, Penelope (coordinator). 2001. "Philippines: Mining a Sacred Mountain: Protecting the Human Rights of Indigenous Peoples." Human Rights Impact Assessments for Foreign Investment Projects. https:/www.slideshare.net/ no2mininginpalawan/mining-a-sacred-mountainprotecting-the-human-rights-ofindigenous-communities.

Shepherd, Bede, and A. Lin Neumann. 2007. "Scared Silent: Impunity for Extrajudicial Killings.” Human Rights Watch 19, no. 9. https://www.hrw.org/ reports/2007/philippines0607.

Sison, Jose Maria. 2013. Detention and Defiance against Dictatorship: Selected Writings, 1977-1986. Utrecht, The Netherlands: International Network for Philippine Studies.

Vitug, Marites Danguilan, and Glenda M. Gloria. 2000. Under the Crescent Moon: Rebellion in Mindanao. Quezon City: Ateneo Center for Social Policy and Public Affairs. 